\title{
尿路結石症に拈ける尿中カルシウムイオン活量の研究
}

\author{
第 1 報 イオン選択電極による測定 \\ 和歌山県立医科大学泌尿器科学教室 森 本 鎮 義
$($ 主集
}

\section{STUDIES ON URINARY CALCIUM ION ACTIVITY IN UROLITHIASIS}

1. Determination of Calcium Ion Activity with an Ion-Selective Electrode

\author{
Shigeyoshi Morimoto \\ Department of Urology, Wakayama Medical College \\ (Director: Prof. T. Ohkawa)
}

Calcium ion activity is physicochemical value corresponding to effective calcium ion concentration, which directly relates to the saturation level of calcium complex in solution. Therefore, urinary calcium ion activity seems to be an important factor for the formation of urinary calculus. A method, using an ionselective electrode, for the direct measurement of urinary calcium ion activity is described here. Calcium ion activity values of standard solutions were calculated by Debye-Hückel equation, and used to calibrate the electrode.

There was a good agreement between the calculated and measured values of calcium ion activities in a series of $\mathrm{CaCl}_{2}-\mathrm{NaCl}$ solutions. $\mathrm{pH}(5 \sim 8)$ and temperature $\left(10 \sim 40^{\circ} \mathrm{C}\right)$ had no influence on the determination in $\mathrm{CaCl}_{2}-\mathrm{NaCl}$ solutions.

Reproducibility of calcium ion activity determination in urine was satisfactory. In urine, however, the measured activities were increased in proportion to the temperature, and decreased by alkalinization, which induced precipitation of calcium salt.

Urinary calcium ion activity $\left(25^{\circ} \mathrm{C}\right)$ of calcium stone formers was significantly higher than that of healthy controls. There was a significant correlation between urinary calcium ion activities and total calcium concentrations. The ratio of calcium ion activity to total calcium concentration showed no difference between controls and stone formers, but it was significantly lower in stone formers with crystalluria.

要旨：カルシウムイオン $\left(\mathrm{Ca}^{++}\right)$活量は, 有効 $\mathrm{Ca}^{++}$濃度を示すところの物理化学的な值であり, 溶液中 $\mathrm{Ca}$ 塩の飽和度に直接関与寸るとされている，そこで, 尿中 $\mathrm{Ca}^{++}$活量は尿路結石形成にとって重要な要 素になりえるものとの考えから, $\mathrm{Ca}^{++}$選択電極を用いて, 尿中 $\mathrm{Ca}^{++}$活量の測定を試み, その基礎的検討 ならびに臨床での測定結果を報告した。標準液の $\mathrm{Ca}^{++}$活量值を Debye-Hückel 式に従い計算し，これに よってキャリブレーションを行った。

一連の $\mathrm{CaCl}_{2}-\mathrm{NaCl}$ 溶液において, 計算による $\mathrm{Ca}^{++}$活量值および電極による実測值が, ほぼ一致する ことを確認した。 また, $\mathrm{pH}(5 \sim 8)$ および温度 $\left(10 \sim 40^{\circ} \mathrm{C}\right)$ による測定值への影響は認められなかった。 本法による尿中 $\mathrm{Ca}^{++}$活量測定の再現性は満足すべきものであった。 しかし，尿中 $\mathrm{Ca}^{++}$活量測定にお いては, 温度上昇に比例して測定値は上昇し，またアルカリ化による Ca 塩の析出によって $\mathrm{Ca}^{++}$活量は 低下した。

対照群44名および結石症例群 68 名での 24 時間尿を用いた, $25^{\circ} \mathrm{C}$ 下での $\mathrm{Ca}^{++}$活量測定值は, 各々 $0.201 \pm$ 0.066 (mean $\pm \mathrm{SD})$ および $0.243 \pm 0.104 \mathrm{mM}$ となり, 結石群で有意に高値となった。一方, 尿中 $\mathrm{Ca}^{++}$ 活量および総 $\mathrm{Ca}$ 濃度の間には有意な相関性が認められた. $\mathrm{Ca}^{++}$活量/総 $\mathrm{Ca}$ 濃度比は, 対照群および結 石群の間で差をみなかったが，塩類尿を呈するものでは有意に低值となった。 


\section{緒言}

尿路結石主成分の大半がカルシウム（以下 $\mathrm{Ca}$ と略 す）塩で占められていることから，尿路結石の発生機 序扣よび原因を考学るらえで，尿中 Ca は常に注目さ れて来ている，尿路結石症例の中に過 $\mathrm{Ca}$ 尿症を呈す るものが多いことは，既に周知のところであり，この ことから同時に尿中 Ca 塩はより高い飽和状態にある ものと考兄られている. 尿中に排泄される $\mathrm{Ca}$ の中で, 苳酸あるいは燐酸イオンと結合し, $\mathrm{Ca}$ 塩結晶を形成打 よび増大するうえで重要なものはカルシウムイオン （以下 $\mathrm{Ca}^{++}$と略す）とされ, 従って, 尿路結石症の研 究に扣いて尿中 $\mathrm{Ca}^{++}$定量的に検討することの意義 は大きいものと考える。

今回測定を試みたところの $\mathrm{Ca}^{++}$活量は, 溶液中 $\mathrm{Ca}$ のイオン活性を示す物理化学的な値である，溶液中組 成の化学平衡は, 一般には濃度を用いて計算されるが, 厳密にはこの活量によって決定される，とくに，尿路 結石成分となる苳酸 $\mathrm{Ca}$ などの弱電解質において，そ の溶解性は, $\mathrm{Ca}^{++}$活量および苳酸イオン活量の積, す なわち溶解度積で表現されている1)。尿中においてる 同様であるが2), 溶液中 $\mathrm{Ca}$ 塩の活量積は, 溶解度積値 に対する比をとることによって，飽和状態の指標とな り，不飽和あるいは過飽和が判定される1). 従って，尿 中 $\mathrm{Ca}^{++}$活量の測定により，尿路結石形成における $\mathrm{Ca}$ の要素はより確実に評価されるものと考劣える。

尿中 $\mathrm{Ca}^{++}$活量は, 尿中組成の全てを定量し, 形成さ れる可溶性 complex の安定度定数から、コンピュー ターを用いることによって計算されらるが344)，電極の 測定原理を利用することによって簡便に実測すること が可能である.今回著者は, $\mathrm{Ca}$ 電極を用いた尿中 $\mathrm{Ca}^{++}$ 活量測定の基礎的検討を試み，次いで臨床的応用とし て, 健康人および尿路結石症例での尿中 $\mathrm{Ca}^{++}$活量を測 定し，それぞれを比較検討したので，その結果を併せ 報告する。

\section{1. 基礎的検討}

方 法

1) $\mathrm{Ca}^{++}$活量の理論値
溶液中の組成が明らかな場合, $\mathrm{Ca}^{++}$活量は理論的に 計算されらる值であり，これを求めるための関係式を Fig. 1に示した。すなわち, $\mathrm{Ca}^{++}$活量は個々の溶液中 $\mathrm{Ca}^{++}$濃度および活量係数との積で求められる. 活量係 数は, イオン強度の関数として Debye-Hückel の理論 式より導びかれる。イオン強度が $0.01 \sim 0.3 \mathrm{M}$ の範囲 では Debye-Hückel の第二近似式が成立するとされ て招り5)，尿中イオン強度はこの範囲内に含まれるた め4), この近似式を用いた(Fig. 1, 式 2). 定数Aは, 溶媒の誘電率と温度によって決まるもので, $25^{\circ} \mathrm{C}$ の水 溶液では 0.509 となる ${ }^{5}$ 。 また, イオン強度は, 溶液中 の全てのイオン濃度および各々の価電数より計算され る.

\section{2）測定方法}

$\mathrm{Ca}^{++}$活量測定には, Ionetics 社の Calcium Analyzer Set を用いた。この装置は, $\mathrm{Ca}$ 電極による血清中 $\mathrm{Ca}^{++}$濃度測定用のものであるが, 後述する電極法の測 定原理を利用して, $\mathrm{Ca}^{++}$活量測定に供した。

$\mathrm{Ca}^{++}$活量標準液として, 同社の血清用 $\mathrm{Ca}$ 標準液 （090-020-005P, -010P, -015P）を用いた。これ等標準

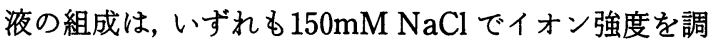
節し，防腐剤として安息香酸ナトリウム $0.417 \mathrm{mM}$ が 添加されたものに, $\mathrm{CaCl}_{2}$ 濃度が0.5, 1.0, $1.5 \mathrm{mM}$ とな るように加えられている6. この組成から, Fig. 1の関 係式に従い, イオン強度, 活量係数拈よび $\mathrm{Ca}^{++}$活量を 計算した(Table 1). その結果, 各標準液の $\mathrm{Ca}^{++}$活量

Fig. 1 Caluculation of theorectical $\mathrm{aCa}^{*}$ value

1. $\mathrm{Ca}^{\#}$ 活量 (Calcium lon Activity : $\mathrm{aCa}^{\#}$ ) $\mathrm{aCa}^{*}=\gamma \times \mathrm{CCa}^{*}$

2. 活量係数 (Activity Coefficient : $\gamma$ )

$$
-\log \gamma=\frac{\mathrm{AZi}^{2} \sqrt{\mu}}{1+\sqrt{\mu}}
$$

3. イオン強度 (Ionic Strength $: \mu$ )

$$
\mu=\frac{1}{2} \Sigma \mathrm{Zi}^{2} \mathrm{Ci}
$$

$\left(\mathrm{cCa}^{\#}\right.$ : $\mathrm{Ca}^{\#}$ 濃度, $\mathrm{A}$ : 定数, $\mathrm{Zi}$ : 荷電数, $\mathrm{Ci}$ : 電解質モル濃度)

Table $1 \mathrm{aCa}^{*}$ values in calcium standards (Ionetics, Inc.)

\begin{tabular}{c|c|c|c}
\hline Calcium Standard & $\begin{array}{c}\text { Ionic strength } \\
(\mu)\end{array}$ & $\begin{array}{c}\text { Activity coefficient } \\
\text { of } \mathrm{Ca}^{+}\left(r \mathrm{Ca}^{+}\right)\end{array}$ & $\begin{array}{c}\text { Activity of } \mathrm{Ca}^{\#} \\
\left(\mathrm{aCa}^{+}\right) \\
\mathrm{mM}\end{array}$ \\
\hline $\mathrm{Ca}^{+} 0.5 \mathrm{mM}$ & 0.152 & 0.275 & 0.137 \\
1.0 & 0.153 & 0.274 & 0.274 \\
1.5 & 0.155 & 0.272 & 0.409 \\
\hline
\end{tabular}


値は各々 $0.137,0.274$ および $0.409 \mathrm{mM}$ となった。

標準液の $\mathrm{Ca}^{++}$活量値によってキャリブレーション を行った後, 被検液である尿あるいは $\mathrm{Ca}$ 溶液に電極 を漫すことにより，デジタルで0.01mM の単位まで活 量値が表示される。この電極装置に, 自動記録計 (Shimazu, U-135)を接続することによって, キャリブ レーションはより正確となり，0.001mM の単位まで の活量の読み取りが可能となった，測定に要する検体 量は最小約 $0.5 \mathrm{ml}$ で，測定時間は 1 分以内である。 た，各検体毎に，キャリブレーションを行った。

この他の測定方法としては，尿中 $\mathrm{Ca}$ 濃度は原子吸 光法 (Shimazu, AA-630-12), $\mathrm{pH}$ はガラス電極法 (Corning, M-125) で測定された。

3) $\mathrm{Ca}$ 溶液の作製

$\mathrm{Ca}^{++}$濃度およびイオン強度が異なる一連の $\mathrm{Ca}$ 溶液 を作製し，それ等の $\mathrm{Ca}^{++}$活量について，理論値および
電極法による実測值とを比較した。すすねわ $\mathrm{CaCl}_{2}$ 濃 度が0.5，1.0，2.0，3.0mM，および $\mathrm{NaCl}$ 濃度が 50 , $100,150,200 \mathrm{mM}$ となるよう, 計 16 種類の $\mathrm{CaCl}_{2}-\mathrm{NaCl}$ 溶液を作製し、イオン強度は $\mathrm{NaCl}$ で調節した。この等 $\mathrm{Ca}$ 溶液の $\mathrm{pH}$ は5.84 6.07であった。 $\mathrm{Ca}^{++}$活量測定 における $\mathrm{pH}$ の影響を検討する際には，希釈した $\mathrm{HCl}$ あるいは $\mathrm{NaOH}$ を添加し $\mathrm{pH}$ を調節した。

試薬類はすべて市販の特級規格あるいは分析用のも のを, また水溶液の作製には蒸留水を Millipore 社の Milli-Q System に通した純水を用いた。

\section{結 果}

1）理論值および実測値の比較

作製した $\mathrm{Ca}$ 溶液中の $\mathrm{Ca}$ は $100 \%$ イオン化している あのとして, Fig. 1の式に従い $\mathrm{Ca}^{++}$活量を計算した。

Fig. 2の如く, 理論值と実測值とはほぼ一致すること を確認した。両軸対数表を用いたのは，横軸について

Fig. 2 Comparison of measured $\mathrm{aCa}^{++}$and calculated $\mathrm{aCa}^{++}$in $\mathrm{CaCl}_{2}-\mathrm{NaCl}$ solutions
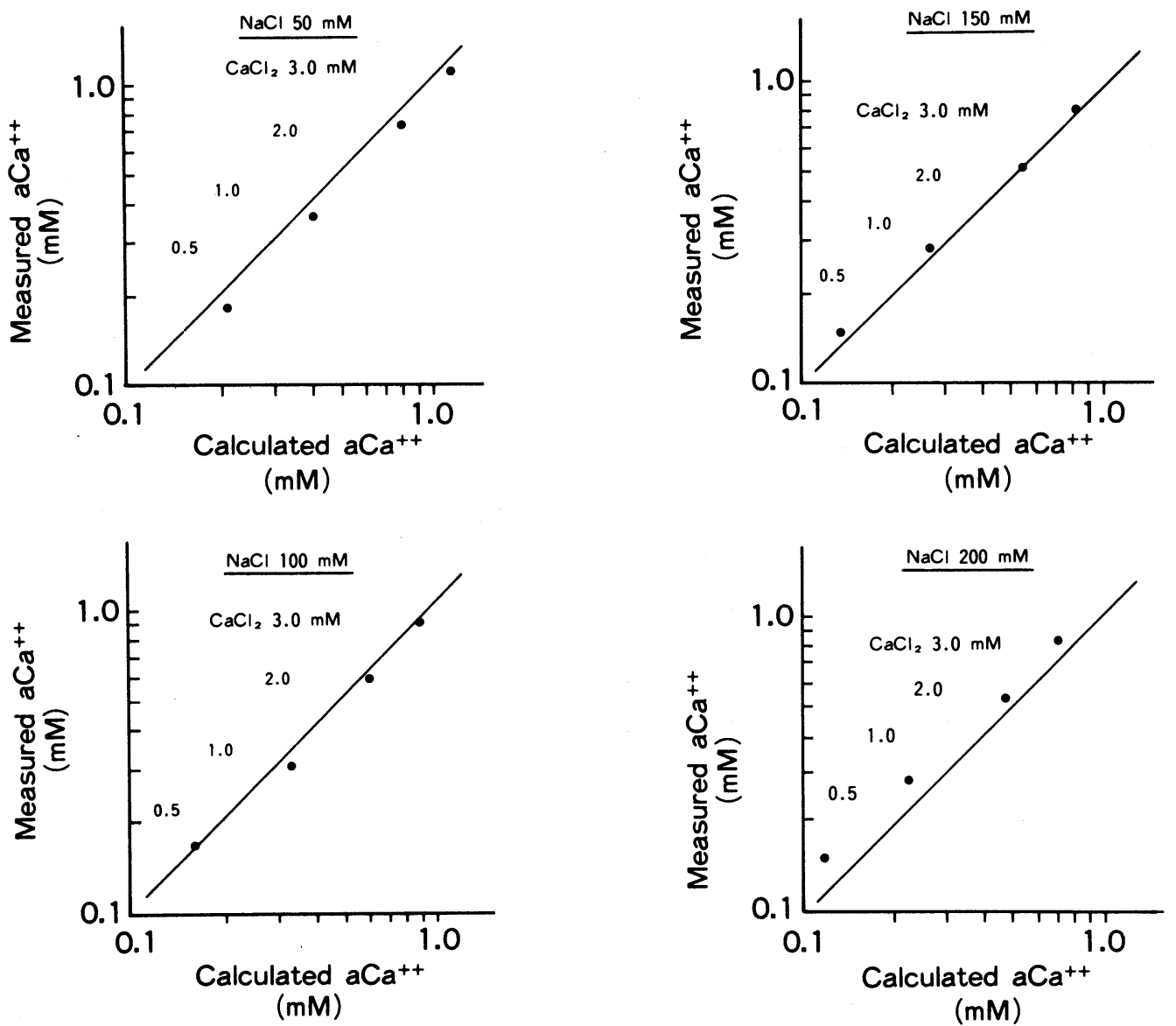
Fig. 3 Effects of $\mathrm{pH}$ and temperature on $\mathrm{aCa}^{++}$ values of $\mathrm{CaCl}_{2} \cdot \mathrm{NaCl}$ solutions
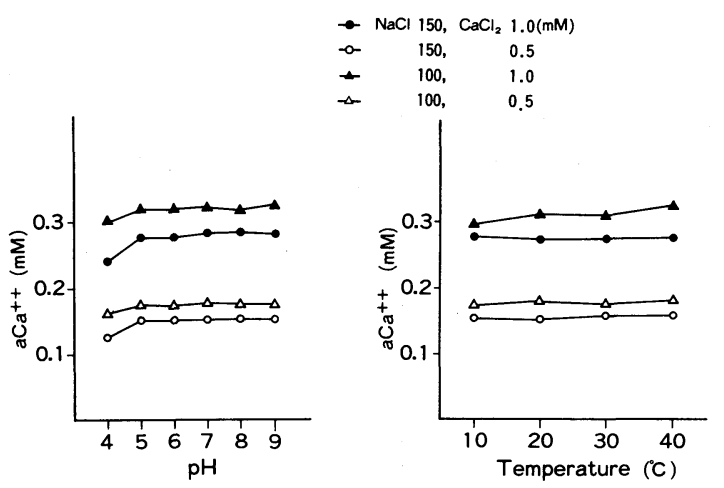

Fig. 4 Effect of temperature on urinary $\mathrm{aCa}^{++}$

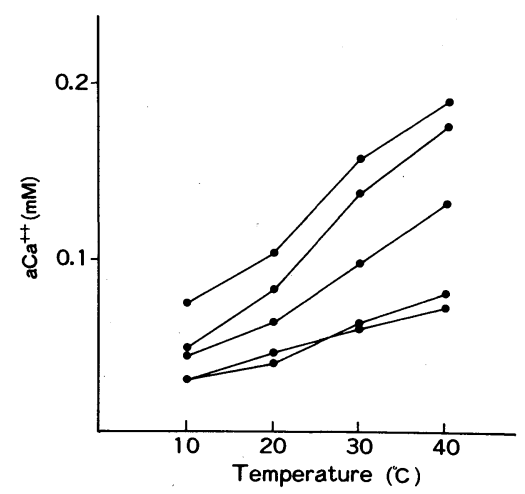

は後に説明するところの Nernst の式に従い，縌軸に ついては Ca 電極装置に logarithm converter が内蔵 されているためである7゙.

2） $\mathrm{pH}$ 抽よび測定温度の影響

$\mathrm{CaCl}_{2}$ 濃度が0.1, $1.0 \mathrm{mM}$ および $\mathrm{NaCl}$ 濃度が 100 , $150 \mathrm{mM}$ の 4 種類の $\mathrm{Ca}$ 溶液を用いて, $\mathrm{Ca}^{++}$活量測定 に拈ける $\mathrm{pH}$ おょび温度の影響について検討した (Fig. 3). pH 4では $\mathrm{Ca}^{++}$活量測定値に僅かの低下をみ たが, 尿の生理的 $\mathrm{pH}$ 範囲である 5 ないし 8 の間では, 測定值に変化は認められなかった。 また, 温度の影響 については, $10 な い し 400^{\circ} \mathrm{C}$ の間では測定値に変化を認 めなかった。この場合, 電極, 標準液拈よび被検液は, いずれも同一温度となるよう調節された。

ヒト尿での $\mathrm{Ca}^{++}$活量測定における, $\mathrm{pH}$ 抽よび温度 の影響については, まず温度では, その上昇に比例し て測定値にはかなりの上昇が見られた(Fig. 4).Ca 溶 液での測定に際しては，温度による影響がみられな かったことと考え合わせると, 尿中では温度の上昇に
Fig. 5 Effect of temperature on serum $\mathrm{aCa}^{++}$

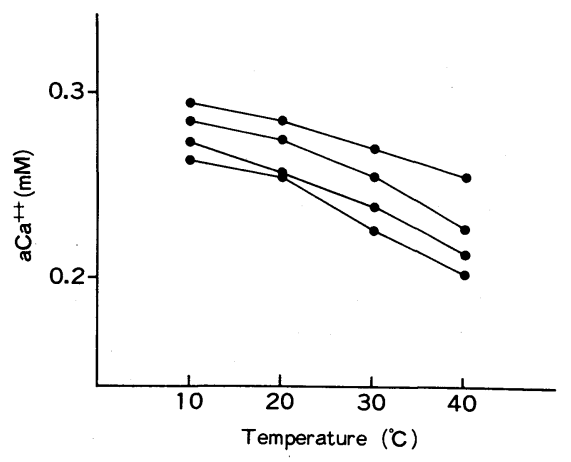

Fig. 6 Effect of $\mathrm{pH}$ on urinary $\mathrm{aCa}^{++}$
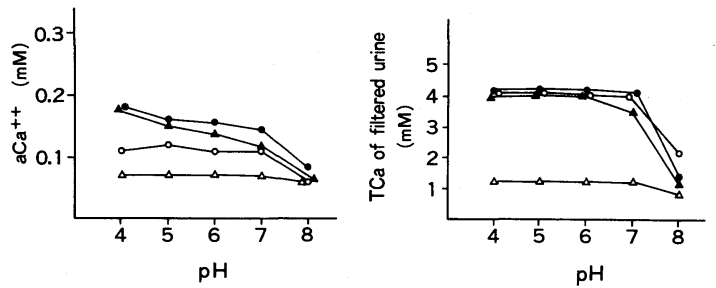

Fig. 7 Reproducibility of urinary $\mathrm{aCa}^{++}$values

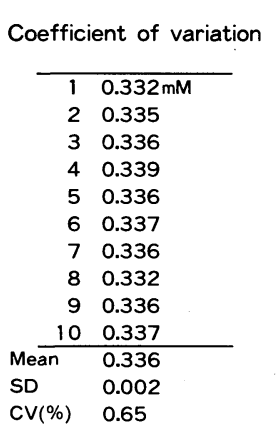

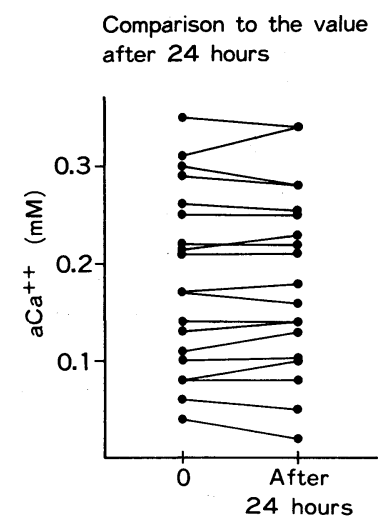

より， $\mathrm{Ca}^{++}$活量が高くなるものと考えられる。また， 対比する意味で, 血清中 $\mathrm{Ca}^{++}$活量測定での温度の影響 をみたところ, 血清では温度上昇により測定値の低下 が認められた(Fig. 5)。このことから， $\mathrm{Ca}^{++}$活量測定 に拀いては温度を一定にすることが必要であり，以後 の検討ではすべて $25^{\circ} \mathrm{C} に$ 温度設定を行った。

次に, 4 検体の尿を $\mathrm{HCl}$ あるいは $\mathrm{NaOH}$ 液で $\mathrm{pH}$ 調節し, $\mathrm{Ca}^{++}$活量を測定したところ, $\mathrm{pH} 7$ あるいは 8 以上のアルカリ化により, $\mathrm{Ca}^{++}$活性量の低下を認めた (Fig. 6). この時, 尿は肉眼的に白濁された。そこで, 
各 $\mathrm{pH}$ での尿を Millipore filter $(0.45 \mu \mathrm{m})$ に通し，そ の濾液中 $\mathrm{Ca}$ 濃度を測定した結果, $\mathrm{Ca}$ 濃度の低下を認 めたことから,尿のアルカリ化による $\mathrm{Ca}^{++}$活量の低下 は, Ca 塩の析出によることが明らかとなった。

3）再現性

尿での $\mathrm{Ca}^{++}$活量測定值について，その再現性を検討 した (Fig. 7). 同一検体の 10 回連続測定では，その変 動係数 (CV) 值は0.65\%であった．次に，19検体につ いて，24時間 $25^{\circ} \mathrm{C} て ゙$ 放置した後に再測定したが，その 誤差は $0.03 \mathrm{mM}$ 以内であり，いずれも良好な再現性を 示した.

\section{2. 臨床的検討}

対象および方法

健康対照例怙よび Ca 塩を結石主成分とする尿路結 石症例を対象として, その24時間尿の総 $\mathrm{Ca}$ 濃度, $\mathrm{Ca}^{++}$ 活量, $\mathrm{pH}$ および尿量を測定し比較検討を行った. 24 時 間蓄尿には防腐剤などの添加は行わなかった。結石症 例のらち，尿中 Ca 濃度が, 尿を Millipore filter $(0.45$ $\mu \mathrm{m} ）$ に通すことにより，0.2mM 以上の低下をみたも のは, 著明な塩類尿を有するものとして別に分類した。 対照例に执いても 2 例で塩類尿を認めたが，今回の検 討からは除外された。対照群は44名（男子34，女子10

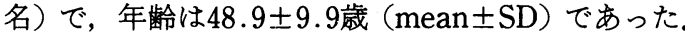
結石非塩類尿群（以下結石群と略す）扣よび結石塩類 尿群（以下塩類尿群と略す）は，各々68名（男子54, 女子14名）拈よび12名（男子11，女子 1 名）で，年齢 は45.3土12.1歳および $45.5 \pm 8.8$ 歳であった. 3 群にお ける年齢には有意差を認めなかった。尿中 $\mathrm{Ca}^{++}$活量 は，前述の $\mathrm{Ca}$ 電極を用いた方法により $25^{\circ} \mathrm{C} て ゙$ 測定さ れた。

\section{結果}

対照群, 結石群および塩類尿群におけりる24時間尿の， 総 $\mathrm{Ca}$ 濃度 $(\mathrm{TCa}), \mathrm{Ca}^{++}$活量, $\mathrm{Ca}^{++}$活量/総 $\mathrm{Ca}$ 濃度 比，Ca 排泄量， $\mathrm{pH}$ 拉よび尿量を Table 2に示した。

まず, 対照群および結石群の間で, 尿中 $\mathrm{Ca}^{++}$活量お よび総 $\mathrm{Ca}$ 濃度について比較検討を行った（Fig. 8,

Fig. 8 Urinary $\mathrm{aCa}^{++}$and total calcium concentration in controls and stone formers
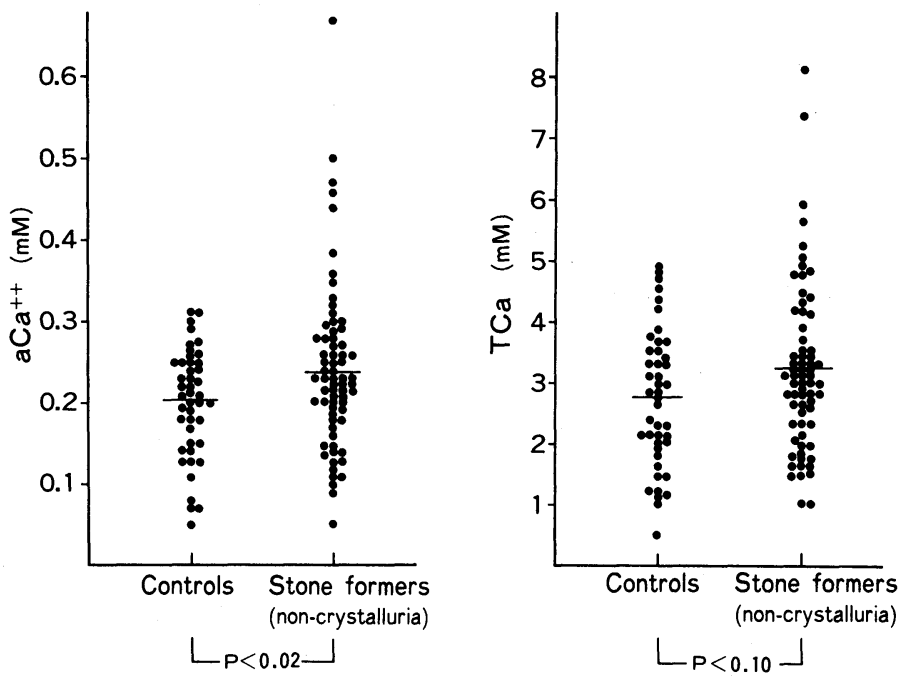

Table 2 Mean values $( \pm \mathrm{SD})$ of urinary variables in controls and stone formers

\begin{tabular}{l|c|c|c|c|c|c|c}
\hline & $\begin{array}{l}\text { No. } \\
\text { Pts. }\end{array}$ & $\begin{array}{c}\mathrm{TCa} \\
(\mathrm{mM})\end{array}$ & $\begin{array}{c}\mathrm{aCa}^{+} \\
(\mathrm{mM})\end{array}$ & $\mathrm{aCa}^{+} / \mathrm{TCa}$ & $\begin{array}{c}\mathrm{Ca} \\
\text { Excretion } \\
(\mathrm{mmol} / 24 \mathrm{hr})\end{array}$ & $\mathrm{pH}$ & $\begin{array}{c}\text { Urine } \\
\text { Volume } \\
(\mathrm{ml} / 24 \mathrm{hr})\end{array}$ \\
\hline $\begin{array}{l}\text { Controls } \\
\begin{array}{l}\text { Stone Formers } \\
\text { (non-crystalluria) }\end{array}\end{array}$ & 44 & $2.76 \pm 1.12$ & $0.201 \pm 0.066$ & $0.082 \pm 0.034$ & $2.91 \pm 1.09$ & $6.19 \pm 0.37$ & $1090 \pm 310$ \\
$\begin{array}{l}\text { Stone Formers } \\
\text { (crystalluria) }\end{array}$ & 12 & $4.24 \pm 1.36$ & $0.243 \pm 0.104$ & $0.078 \pm 0.025$ & $5.09 \pm 2.30$ & $5.95 \pm 0.49$ & $1680 \pm 720$ \\
\hline
\end{tabular}


Fig. 9 Correlation between urinary $\mathrm{aCa}^{++}$and total calcium concentration in controls and stone formers

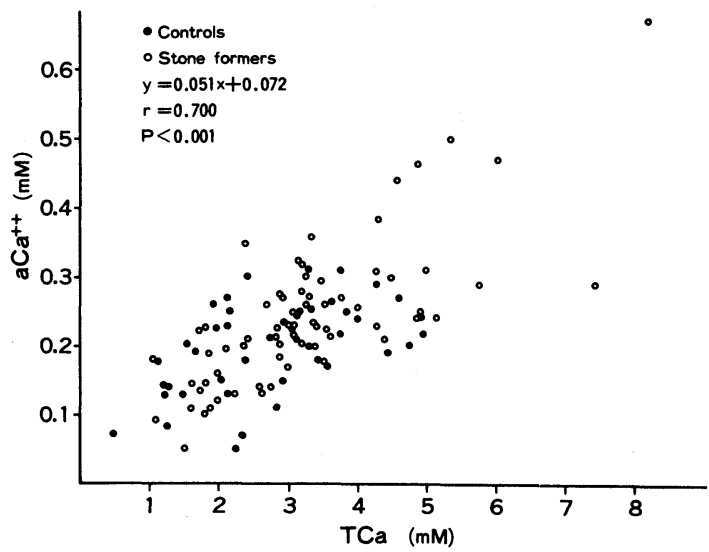

Fig. 10 Ratios of $\mathrm{aCa}^{++}$to total calcium concentration of urine in controls and stone formers

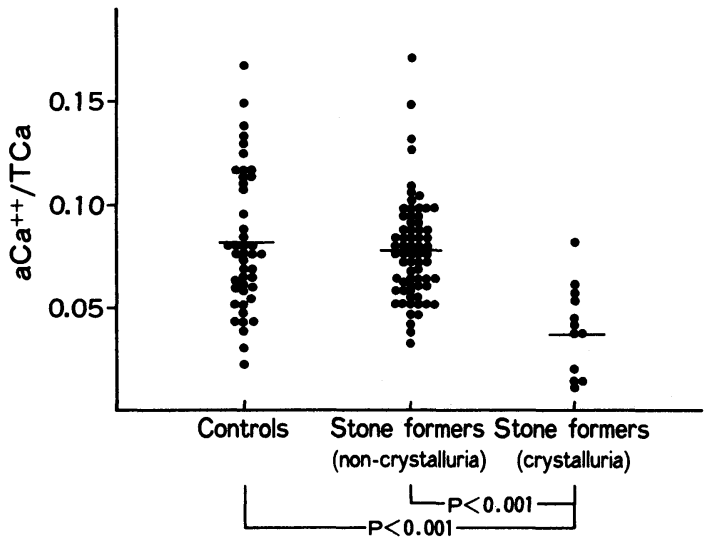

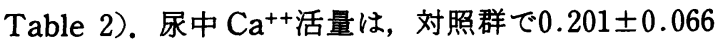
$\mathrm{mM}$, 結石群で0.243 $0.0104 \mathrm{mM}$ となり, 結石群で有 意に高値となった $(\mathrm{p}<0.02)$. 総 $\mathrm{Ca}$ 濃度は，対照群で $2.76 \pm 1.12 \mathrm{mM}$, 結石群で $3.24 \pm 1.36 \mathrm{mM}$ となり,結石
群で高い傾向が見られた。両群での個々の症例におけ る総 $\mathrm{Ca}$ 濃度および $\mathrm{Ca}^{++}$活量值をプロットすると (Fig. 9), 両群の間でその分布に明らかな差を認めず, 一方総 $\mathrm{Ca}$ 濃度および $\mathrm{Ca}^{++}$活量値の間には有意な相 関性が認められた（ $\mathrm{r}=0.700, \mathrm{p}<0.001)$. 従って, 結 石群で $\mathrm{Ca}^{++}$活量が高値であるのは, 総 $\mathrm{Ca}$ 濃度に依存 するところが大きいものと考えられた，

そこで，総 $\mathrm{Ca}$ 濃度に対する $\mathrm{Ca}^{++}$活量の比について 比較検討したところ（Fig. 10, Table 2)，対照群で $0.082 \pm 0.034$, 結石群で0.078 00.025 となり, 両群の 間で差を認めなかった。他方，塩類尿群では0.038土 0.021 となり，他の 2 群に比して有意に低值となった $(\mathrm{p}<0.001)$.

以上の結果を分析するにあたって, Table 2で示し た測定值の平均について 3 群の間で比較検討を行った (Table 3)。その結果, 尿中 $\mathrm{Ca}$ 排泄量は, 結石群扰よ び塩類尿群の間で差を認めず，両群とも対照群と比較 して有意に高値であった，尿量は，結石群で有意に多 く，一方対照群と塩類尿群の間では差をみなかった。 これ等のことを反映して, 総 $\mathrm{Ca}$ 濃度は塩類尿群で有 意に高く，次いで結石群および対照群の順に高値で あった。 $\mathrm{pH}$ は 3 群の間で有意差を認めなかった。

\section{考按}

血清中 $\mathrm{Ca}^{++}$濃度の測定には, 現在広く $\mathrm{Ca}$ 電極装置 が用いられているが，この $\mathrm{Ca}$ 電極そのものは $\mathrm{Ca}^{++}$濃 度ではなく $\mathrm{Ca}^{++}$活量に反応する.そこで, 電極法の測

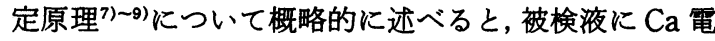
極を漫した時, 電極先端にある $\mathrm{Ca}^{++}$に選択的に感応す る膜を介して，電極内の一定の $\mathrm{Ca}^{++}$活量と被検液中 $\mathrm{Ca}^{++}$活量の差によって電位差が生ずるものである. 生 ずる電位差は, Nernst の式

$$
\mathrm{E}=\frac{\mathrm{RT}}{\mathrm{ZF}} \ln \frac{\mathrm{a}_{0}}{\mathrm{a}_{1}}
$$

を満足するとされている。ここで， $\mathrm{E}$ は膜電位， Rは

Table 3 Probability for significant differences between three groups for urinary variables

\begin{tabular}{l|c|c|c|c|c|c}
\hline & $\mathrm{TCa}$ & $\mathrm{aCa}^{*}$ & $\mathrm{aCa}^{*} / \mathrm{TCa}$ & $\begin{array}{c}\mathrm{Ca} \\
\text { Excretion }\end{array}$ & $\mathrm{pH}$ & $\begin{array}{c}\text { Urine } \\
\text { Volume }\end{array}$ \\
\hline $\begin{array}{c}\text { Controls vs. } \\
\text { S.F. (non-cryst.)* }\end{array}$ & n.s. $(<0.1)$ & $<0.02$ & n.s. & $<0.001$ & n.s. $(<0.1)$ & $<0.001$ \\
$\begin{array}{c}\text { S.F. (cryst.)** vs. } \\
\begin{array}{c}\text { Controls } \\
\text { S.F. (cryst.) vs. } \\
\text { S.F. (non-cryst.) }\end{array}\end{array}$ & $<0.001$ & n.s. & $<0.001$ & $<0.001$ & n.s. & n.s. \\
\hline
\end{tabular}

* stone formers (non-crystalluria)

** stone formers (crystalluria) 
ファラデー定数, $T$ は絶対温度, $Z$ は荷電数, $a_{1}$ は電極 内 $\mathrm{Ca}^{++}$活量掞よび $\mathrm{a}_{0}$ は被検液中 $\mathrm{Ca}^{++}$活量である。膜 電位を測定するためには電流 circuit の形成が必要と され，Ca 電極に加えて標準電極が組み合わされる。標 準電極は, 被検液の組成には影響を受けずに一定の電 位を保つもので，この標準電位 $\left(\mathrm{E}^{\prime}\right)$ を式(1)に加え, $\mathrm{Ca}^{++}$の荷電数の挿入, および自然対数を常用対数に置 換すると，

$$
\mathrm{E}=\mathrm{E}^{\prime}+\frac{2.3 \mathrm{RT}}{2 \mathrm{~F}} \log \frac{\mathrm{a}_{0}}{\mathrm{a}_{1}}
$$

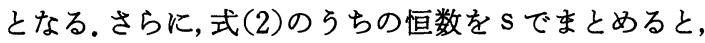

$$
\mathrm{E}=\mathrm{E}^{\prime}+\mathrm{S} \log \mathrm{a}_{0}
$$

となる7). 従って, $\mathrm{Ca}$ 電極によって生ずる電位は被検 液中の $\mathrm{Ca}^{++}$活量の対数值に比例したものとなる。この 測定原理は, 他のイオン選択性電極でも同様である.

血清に扔いて $\mathrm{Ca}^{++}$濃度測定が可能である理由は, 血 清の諸電解質濃度が生体の調節機構によってほぼ一定 に保たれ，血清中イオン強度に個人差が無いためであ る.すなわち, 血清のイオン強度は約 $0.16 \mathrm{M}$ とされて おり，これと同じイオン強度を有する $\mathrm{Ca}$ 溶液を標準 液とすることによって $\mathrm{Ca}^{++}$濃度が測定されう $3^{9) \sim 11)}$. 一方尿に拈いては個々の尿によって電解質濃 度およびイオン強度は著しく異なるため，画一な標準 液による $\mathrm{Ca}^{++}$濃度の測定は不可能である. しかしなが ら，もしイオン強度に影響する尿中電解質のらち主要 なものを個々の尿で定量し，これと同じ濃度の電解質 溶液に $\mathrm{Ca}^{++}$が加光られた標準液を各尿検体に対し作 製することが出来れば, 尿でも電極法による $\mathrm{Ca}^{++}$濃度 の測定は可能となる3 ${ }^{312)}$.

電極法による $\mathrm{Ca}^{++}$濃度測定には, 以上のように被検 液および標準液のイオン強度を同一に調整することが 必要とされるが, $\mathrm{Ca}^{++}$活量を測定するらえでは被検液 のイオン強度は問題とならない, 既知の $\mathrm{Ca}^{++}$活量を有 する標準液でキャリブレーションを行えば, 被検液中 の他のイオン組成やイオン強度に関係なく, $\mathrm{Ca}^{++}$活量 が測定される11. しかしながら，ここで銘記すべきこと は, 単独イオンの活量は厳密には熱力学的な裏付けを もって定義されたものでなく，また熱力学的手法に よっては実測されないもので, 電解質ではその構成イ オンの平均活量が測定されるにすぎない(13)14). このこ とは, 単独イオンの活量を扱う場合に常につきまう 問題であるが，Debye-Hückel の理論式を用いること によって打执よその解決がっくものとされ，熱力学以 外の手法によって理論的には単独イオンについての活
量を決めることが可能とされている14). Kielland $(1937)^{13)}$ は，いくつかのイオン強度下に拈ける種々の 単独イオンの活量係数について, Debye-Hückel 式を modify した実用式から求めた值, およびこれとは独立 した有効イオン直径の計算から求められた值と，過去 に熱力学的に実測されている平均活量係数とを比較 し，いずれも一致したことを報告している。また， Grima and Brand (1977) ${ }^{15)}$ は，Debye-Hückel 式より 計算された溶液中 $\mathrm{Ca}^{++}$活量値を用いて, $\mathrm{Ca}$ 電極の測 定電位に及ぼす種々の要因について検討を行ってい る。

$\mathrm{pH}$ が，ある溶液中の水素イオン活量の負の対数と 定義されることは周知のところであり，電極法による 測定は最も正確なものとして普及されている。この場 合も, 単独イオンの活量が扱われ, Debye-Hückel 式に 基づいて計算された標準緩衝液の $\mathrm{pH}$ でキャリブレー ションがなされている。米国の National Bureau of Standards（NBS）で採用された $\mathrm{pH}$ 測定用の標準液 が広く使用されているが，国によっては異なる標準液 が用いられているため, $\mathrm{pH}$ 測定值にも僅かな差を認 めるとされている ${ }^{14)}$. 従って, 電極法を用いて単独イオ ンの活量を測定するとき，ある理論式からイオン活量 を計算したところの標準液との比較によって，被検液 中イオン活量が求められると，理解しなければならな い. 例えば, Beynon (1981) ${ }^{16)}$ の報告では, $150 \mathrm{mM}$ $\mathrm{NaCl}$ でイオン強度を調節した $0.5 \sim 5.0 \mathrm{mM} \mathrm{CaCl}$ 溶 液を標準液として, 測定した被検液中 $\mathrm{Ca}^{++}$活量は標準 液での $\mathrm{Ca}^{++}$濃度值で表現されている. 当然ながら，そ こで記載された数值は， $\mathrm{Ca}^{++}$活量拉よび $\mathrm{Ca}^{++}$濃度い ずれをも示するのではないが，電極法における標準液 の本質的意義からみて，このような扱い方も可能であ ると考觉る。著者が用いた標準液は, 血清中 $\mathrm{Ca}^{++}$濃度 測定用として Ionetics 社から市販されているもので あり, その $\mathrm{Ca}^{++}$活量値の計算には, Gold が提唱したと されている Debye-Hückel の第二近似式を用いたが, これは提唱されている多くの実用式の中でも最も一般 的なものである ${ }^{1117)}$.

$\mathrm{Ca}$ 電極は，文字通り $\mathrm{Ca}^{++}$に選択的に感応して膜電 位を生ずるが，共存する他の陽イオンによってもある 程度の干渉を受け, 従って前述した式(3)は, より正確 には

$$
\mathrm{E}=\mathrm{E}^{\prime}+\mathrm{S} \log \left(\mathrm{a}_{\mathrm{o}}+\sum_{1} \mathrm{~K}_{1} \mathrm{a}_{1}{ }^{2 / Z_{1}}\right.
$$
となる ${ }^{89915)}$.ここで, $a_{1}$ は共存する干渉イオンの活量, $Z_{1}$ はその荷電数であり, $\mathrm{K}_{1}$ はその選択定数で $\mathrm{Ca}^{++}$で 
1 としたときの干渉イオンでの值である. Ionetics 社 の $\mathrm{Ca}$ 電極では選択定数の詳細は明らかにされていな いが， $150 \mathrm{mM} \mathrm{NaCl}$ 液に電極を浸した時の background としての電位は十分低く，また著者も確認した ところの Nernst 効果 (Fig. 2) は満足すべきものとさ れている7). Orion 社の $\mathrm{Ca}$ 電極では，尿中で問題とな る陽イオンの選択定数は, $\mathrm{KH}^{+}=10^{5}, \mathrm{KNa}^{+}=\mathrm{KK}^{+}=$ $\mathrm{KNH}_{4}^{+}=10^{-4}, \mathrm{KMg}^{++}=0.014$ とされ ${ }^{8)}$ ，これらの尿中濃 度からみて，干渉イオンによる膜電位の誤差はごく僅 かなものと考学られる. 水素イオンの選択定数は非常 に高いが，水素イオン濃度から考光て尿の生理的 $\mathrm{pH}$ 範囲内では問題とならない。しかし，PH 5 以下では水 素イオンの影響をうけて，pH の低下に従い膜電位は 高くなる。Ca 溶液を用いた $\mathrm{pH}$ の影響の検討に招い て, pH 4で $\mathrm{Ca}^{++}$活量測定値が僅かに低下したことは 逆の結果となるが，これは Ca 電極の種類によって生 ずるくぼみ現象とも考兄られる18).

尿中 $\mathrm{Ca}^{++}$活量が温度の上昇に比例して高くなると いら，これまでの記載は見られなかった。 $10 \sim 40{ }^{\circ} \mathrm{C} の$ 間で認めた尿中 $\mathrm{Ca}^{++}$活量値の変化は, Debye-Hückel およびNernst 式に含まれるところ絶対温度の影響で は説明されない，尿中 $\mathrm{Ca}$ の約 $50 \%$ は可溶性 complex を形成し，残る50\%がイオン化しているものと報告さ れているが3), 温度上昇がこの尿中 $\mathrm{Ca}$ 分画に影響を与 えた可能性も考学られる。何故なら，まず溶液中 $\mathrm{Ca}$ が ほぼ100\%イオン化している作製した Ca 溶液では, 温 度变化による $\mathrm{Ca}^{++}$活量測定值への影響は見られな かった. 次に, 血清中 $\mathrm{Ca}^{++}$活量が温度上昇に逆比例し て僅かに低下したことは, Arnold ら (1968) ${ }^{199}$ の報告と 一致するところで，これは温度上昇による限外滤過性 $\mathrm{Ca}$ 分画の減少に伴なら $\mathrm{Ca}^{++}$濃度の低下に依るもの之 考兄られる ${ }^{10) 20)}$. 従って, 測定方法上の問題ではなく, 実際に尿中 $\mathrm{Ca}^{++}$活量は温度によって变化したものと 判断された。

用いた $\mathrm{Ca}$ 電極は dip 型のもので，電極装置には温 度調節が施されていない，むしろこのため, 測定温度 の設定は自由になるが, 種々の試みの中で, この Ca 電 極は磁力あるいは電気的雾囲気によって測定電位に大 きな変動を示した. 恒温水槽, 恒温灌流装置あるいは, magnetic stirrerを用いた測定では，いずれも異常な 高値を示した。このため，測定温度に関する検討にお いては，プラスチック製の bath に標準液および被検 液の入った試験管と，その周囲に数本の水温計を立て て，熱湯あるいは氷を入れながら用手的に擋汼するこ
とによって温度調節を行った。電気恒温器 (Yanagimoto, B-2A) では内部が金網によってシール ドされているためか，測定電位は非常に安定していた ので， $25^{\circ} \mathrm{C}$ に調節したこの恒温器の中あるいは同温度 の室内で尿中 $\mathrm{Ca}^{++}$活量は測定された。

$\mathrm{Ca}^{++}$活量は, $\mathrm{Ca}^{++}$濃度と異なり尿中 $\mathrm{Ca}$ の分画を示 すものでなく，イオン活性あるいは有効イオン濃度を 意味するが，当然ながら尿量増大による希釈によって も影響される，但し，これまで説明した如く，尿量が 2 倍になれば活量は $1 / 2$ となる性質のものではない. 臨 床的検討の結果を考察するにあたって気付かれたこと は, 結石群の 24 時間尿量が他の 2 群に比して有意に多 く，これは医師の指導や患者自身の知識により日頃か ら経口水分を多く摄取しているためと推察される。こ のため, 結石群での尿中総 $\mathrm{Ca}$ 濃度は, 対照群と比較し て高い傾向にあるものの有意差には至らなかったが, $\mathrm{Ca}^{++}$活量は結石群で有意に高値となり, 結石群におい ては尿中 $\mathrm{Ca}$ 塩の飽和状態はより高いものと示唆され

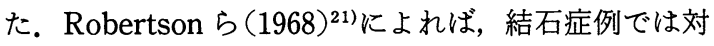
照例と比較して尿中 $\mathrm{Ca}^{++}$濃度および尿中 $\mathrm{Ca}$ のイオ ン化率はより高值であったと報告されているが， $\mathrm{Ca}^{++}$ 活量/総 $\mathrm{Ca}$ 濃度比については両者の間で差を認めな かった.

結石症例の 2 群（結石群および塩類尿群）の間では Ca 排泄量に差を認めず,いずれも対照群に比して高値 であったことから，結石症例に打いて塩類尿を呈する か否かは尿量によって左右される所が大きいことを示 すものであった。一方, 尿 $\mathrm{pH}$ は両群で有意差をみない が, 塩類尿群でやや高く，また $\mathrm{pH}$ が 7 以上であったも のは結石群で68例中 2 例, 塩類尿群で12例中 4 例で あったことからも, 塩類尿の発生には $\mathrm{pH}$ す関与され ていた。アルカリ化に依る場合も含めて, 塩類尿で $\mathrm{Ca}^{++}$活量が低下したことは, $\mathrm{Ca}$ 塩についてょり過飽 和であった尿では, その結晶形成のため見かけの $\mathrm{Ca}^{++}$ 活量は低下することを意味し, 塩類尿の有無によって 尿中 $\mathrm{Ca}^{++}$活量測定值の意義は異なるものと考元られ た.

\section{結 語}

（1） $\mathrm{Ca}^{++}$選択電極の測定原理を利用して，尿中 $\mathrm{Ca}^{++}$活量の測定を試みた。 Debye-Hückel 式を用いて 標準液の $\mathrm{Ca}^{++}$活量を計算し, その値でキャリブレー ションを行った.

（2）作製した $\mathrm{Ca}$ 溶液の $\mathrm{Ca}^{++}$活量について, その理 論值および Ca 電極による実測值がほぼ一致すること 
を確認した。 $\mathrm{Ca}$ 溶液では, 通常扱われる範囲の $\mathrm{pH}$ お よび温度による測定値への影響は認められなかった。

（3）尿では, 温度の上昇に比例して $\mathrm{Ca}^{++}$活量測定值 にかなりの上昇がみられるため, 測定温度の設定が必 要とされた，尿のアルカリ化によって Ca塩が析出さ れ，これと共に尿中 $\mathrm{Ca}^{++}$活量の低下を認めた。

（4）本法による尿中 $\mathrm{Ca}^{++}$活量測定の再現性は満足 すべきものであった。

（5）対照群44名および結石群68名での24時間尿の $\mathrm{Ca}^{++}$活量は, 各々 $0.201 \pm 0.066 \mathrm{mM}$ お。び $0.243 \pm$ $0.104 \mathrm{mM}$ であり, 結石群で有意に高值となった。一 方, 尿中 $\mathrm{Ca}^{++}$活量および総 $\mathrm{Ca}$ 濃度の間には有意な相 関性が認められた。

(6) $\mathrm{Ca}^{++}$活量/総 $\mathrm{Ca}$ 濃度比は, 対照群および結石群 の間で差をみなかったが，塩類尿群（12名）では他の 2 群に比して有意に低值となった。

（7） $\mathrm{Ca}^{++}$活量は尿中 $\mathrm{Ca}$ 塩の飽和状態に直接関与す るとされている物理化学的な值であるが, $\mathrm{Ca}$ 電極を用 いて簡便に測定しらることを示した。 また，塩類尿で は見かけの $\mathrm{Ca}^{++}$活量は低下するため, 非塩類尿とでは 尿中 $\mathrm{Ca}^{++}$測定值の意義は異なるものと考えられる。

稿を終るにあたり，御指導ならびに御校閲を賜った恩師 大川順正教授に深く感謝の意を表しますとともに, 種々御 教示, 御助言を頂いた找野庄一講師に感謝致します。

\section{文 献}

1) Freiser, H. and Fernando, Q.: Ionic equilibria in analytical chemistry. 1 st. ed. p. 125-143, Robert E. Krieger Publishing Co., Florida, 1963.

2) Pak, C.Y.C. and Holt, K.: Nucleation and growth of brushite and calcium oxalate in urine of stone-formers. Metabolism, 25, 665-673, 1976.

3) Robertson, W.G.: Measurement of ionized calciuim in biological fluids. Clin. Chim. Acta, 24, 149-157, 1969.

4) Pak, C.Y.C.: Physicochemical basis for formation of renal stones of calcium phosphate origin: Calculation of the degree of saturation of urine with respect to brushite. J. Clin. Invest., 48, 1914-1922, 1969.

5）本田良行：酸塩基平衡の基礎之臨床. 基礎篇, 第 1 版, p. 22-29, 真興交易医書出版部, 東京, 1974.

6) Personal communication to Ionetics Inc.,

7) Ionetics, Inc., Calcium Analyzer Set. Instruction Manual, Manual No. 007-240-002, California,
1982.

8) Ross, J.W.: Calcium-selective electrode with liquid ion exchanger. Science, 156, 1378-1379, 1967.

9）奥田 稔：カルシウム電極による混合溶液 $\mathrm{Ca}^{++}$ イオン活量の測定. 臨床検査, 13,842-847, 1969.

10) Siggaard-Andersen, O., Thode, J. and Wandrup, J.(越川昭三訳)：血漿中の遊離カルシウム“イオ ン化カルシウム”. 臨床麻酔, 10, 1241-1257, 1981.

11) Moody, G.J. and Thomas, J.D.R.(宗森 信, 日 色武夫共訳)：イオン選択性電極. 第 1 版, $\mathrm{p}$. 54-68, 共立出版, 東京, 1977 .

12) Jacobson, A.L., Singhal, P.C., Mandin, H. and Hyne, J.B. : Urinary ionic calcium and binding sites in normocalciuric idiopathic calcium urolithiasis. Invest. Urol., 17, 218-222, 1979.

13) Kielland, J.: Individual activity coefficients of ions in aqueous solutions. J. Am. Chem. Soc., 59, 1675-1678, 1937.

14) Linnet, N.(本田良行訳)：pH 測定の理論と実際. $\mathrm{pH}$ メーターの基本的理解のための手引き, 第 1 版, p. 13-25, 真興交易医書出版部, 東京, 1971.

15) Grima, J.M. and Brand, M.J.D.: Activity and interference effects in measurement of ionized calcium with ion-selective electrodes. Clin. Chem., 23, 2048-2054, 1977.

16) Beyron, L.L.: Urine calcium activity : A new ion-selective technique. In Urinary Calculus, Brockis, J.G. and Finlayson, B., 1 st. ed., p. 363 -369, PSG Publishing Co., Massachusetts. 1981.

17）Bard, A.J.(松田好晴, 小倉興太郎共訳)：溶液内 1 オン平衡. 理論之計算, 第 1 版, p. 101-112, 化 学同人, 東京, 1978 .

18) Bagg, J. and Vinen, R.: Rosponse of a calcium-selective electrode in acid solutions. Anal. Chem., 44, 1773-1777, 1972.

19) Arnold, D.E., Stansell, M.J. and Malvin, H.H. : Measurement of serum ionic calcium using a specific ion electrode. Am. J. Clin. Path., 49, 627-634, 1968.

20) Robertson, W.G. and Peacock, M.: New techniques for the separation and measurement of the calcium fractions of normal human serum. Clin. Chim. Acta, 20, 315-526, 1968.

21) Robertson, W.G., Peacock, M. and Nordin, B.E. C.: Activity products in stone-forming and non-stone-forming urine. Clin. Sci., 34 , 579-594, 1968.

（1984年11月27日受付） 